\title{
EFEKTIFITAS PENDIDIKAN KESEHATAN TERHADAP TINGKAT KEPATUHAN MINUM OBAT ANTI HIPERTENSI USIA DEWASA
}

\author{
Sri Haryani, Misniarti \\ Politeknik Kesehatan Kementerian Kesehatan Bengkulu, Jurusan Keperawatan, \\ Jalan Indragiri Nomor 03 Padang Harapan Kota Bengkulu \\ sri.ani37@gmail.com
}

\begin{abstract}
Health education is one of the actions that can be performed in order to increase knowledge about health in order to improve the health of particularly age adults with hypertension. This study uses a quasi-experimental design. Samples 36 adulthood with random sampling. The results showed that health education is given a meaningful impact on patients' adherence to antihypertensive drugs in adulthood and family support are factors that affect adherence adulthood in taking antihypertensive medication. This study is recommended to do health education in a sustainable manner through existing activities in the community directly and indirectly.
\end{abstract}

Keywords: health education, the level of anti-hypertensive medication adherence, adulthood

\begin{abstract}
Abstrak: Pendidikan kesehatan merupakan salah satu tindakan yang dapat dilakukan untuk dapat menambah pengetahuan tentang kesehatan dalam rangka meningkatkan derajat kesehatan terutama usia dewasa dengan hipertensi. Penelitian ini mengunakan desain kuasi eksperimen. Sampel 36 usia dewasa dengan random sampling. Hasil penelitian menunjukkan pendidikan kesehatan yang diberikan memberikan pengaruh bermakna terhadap kepatuhan pasien minum obat anti hipertensi pada usia dewasa dan dukungan keluarga merupakan faktor yang mempengaruhi kepatuhan usia dewasa dalam minum obat anti hipertensi. Penelitian ini direkomendasikan untuk dilakukannya pendidikan kesehatan secara berkelanjutan melalui kegiatan yang ada dimasyarakat secara langsung maupun tidak langsung.
\end{abstract}

Kata Kunci: Pendidikan kesehatan, tingkat kepatuhan minum obat anti hipertensi, usia dewasa

Menurut Septiyani (2010), hipertensi umumnya dialami oleh individu usia di atas 45 tahun, tetapi tidak menutup kemungkinan dialami oleh individu berusia muda. Berdasarkan hasil survei bahwa prevalensi kejadian hipertensi di Indonesia sekitar 5-10\%, pada orang dewasa usia 50 tahun ke atas lebih dari $20 \%$, sedangkan berdasarkan jenis kelamin hipertensi pada perempuan ada sekitar $37 \%$ dan laki-laki hanya $28 \%$. Usia lebih atau sama dengan 45 tahun akan memiliki faktor resiko lebih tinggi untuk terjadinya hipertensi dibandingkan usia kurang dari 45 tahun (Meylina, 2005 \& Siziya, 2012).

Menurut American Heart Association bahwa individu yang mengalami hipertensi apabila memiliki tekanan darah sistolik lebih dari $140 \mathrm{mmHg}$ dan tekanan diastolik lebih dari $90 \mathrm{mmHg}$. Diagnosis hipertensi dapat ditegakkan dengan berbagai cara dengan melihat tanda dan gejala yang dialami oleh individu. Pada usia dewasa akan mengalami hipertensi dengan peningkatan tekanan diastolik (Banegas, 2006). Tanda dan gejala yang dialami oleh individu dengan hipertensi akan berbeda dari individu yang satu dengan individu lainnya dan sering juga tidak disadari oleh penderitanya.

Menurut Stanhope and Lancaster (2005), salah satu peran perawat sebagai pemberi pelayanan keperawatan dapat dilakukan dengan pemberian promosi kesehatan dan pencegahan penyakit bagi individu maupun kelompok 
secara umum dan kelompok rentan. Promosi kesehatan dapat dilakukan melalui pendidikan kesehatan yang dapat dilakukan secara langsung baik perorangan, keluarga dan masyarakat yang dilakukan di rumah atau area perawatan. Promosi kesehatan dapat dilakukan melalui pemberantasan penyakit, perbaikan gizi, pemberdayaan masyarakat, meningkatkan dan melindungi kesehatan.

Tiga strategi dasar dalam promosi kesehatan yaitu advokasi kesehatan yang digunakan untuk menciptakan kondisi yang kondusif demi terciptanya proses yang mendorong seluruh komponen masyarakat dalam mencapai seluruh potensi kesehatan dan mediasi untuk menyamakan perbedaan-perbedaan kepentingan di masyarakat untuk mencapai derajat kesehatan yang baik bagi individu. Lima area prioritas dalam promosi kesehatan yaitu mengembangkan kebijakan publik yang berwawasan pada kesehatan, menciptakan lingkungan yang kondusif bagi kesehatan, memperkuat kegiatan yang berwawasan kesehatan di masyarakat dan mengembangkan kemampuan individu serta mengorientasikan kembali tentang pelayanan kesehatan yang ada dan dapat digunakan oleh masyarakat (Charter dalam Herqutanto, 2010).

Pendidikan kesehatan atau penyuluhan kesehatan dapat dilakukan dengan menggunakan media leaflet dan booklet yang dilakukan secara langsung dengan ceramah maupun tidak langsung dengan menggunakan media cetak seperti koran, buku dan majalah (Widodo, 2004 dalam Kumboyo, 2011; Effendy, 2010). Penggunaan alat bantu media massa dalam bentuk majalah, televisi, internet dan surat kabar dalam penyebaran informasi kesehatan lebih menarik karena dapat menampilkan informasi dengan baik yang disertai gambar sehingga mudah untuk diadopsi oleh masyarakat untuk meningkatkan derajat kesehatannya (Gupta \& Sinha, 2010).

Menurut WHO dalam Hashmi (2007), kepatuhan merupakan perilaku seseorang untuk mengikuti suatu diet atau melaksanakan perubahan gaya hidup yang baik sesuai dengan yang disetujui oleh penyedia pelayanan kesehatan. pengukuran kepatuhan pada klien dengan hipertensi dapat menggunakan skala kepatuhan Hill-Bone Scale dengan mengamati dan mengukur obat yang diminum. Hanya sekitar 50\%-70\% pasien yang patuh terhadap pengobatan selama 1 tahun (Qasem, 2011). Berdasarkan etnik, bahwa etnik cina lebih patuh terhadap program pengobatan (Ramli et all, 2012). Namun, menurut Dabbagh (2009), yang menggunakan Morisky-Green Test tentang kepatuhan pasien minum obat hipertensi bahwa tingkat kepatuhannya hanya 54,6\% saja dan dipengaruhi oleh usia yang lanjut, jenis kelamin perempuan, rendahnya tingkat pendidikan, status sosial ekonomi, lamanya mengalami penyakit, pengetahuan tentang menggunakan obat, memikirkan resiko penyakit, adanya penyakit dan perubahan gaya hidup.

Penderita hipertensi usia dewasa di Provinsi Bengkulu tahun 2011 sebanyak 15.074 orang dan di Rejang Lebong tahun 2010 jumlah penderita hipertensi sebanyak 5352 orang, sedangkan tahun 2011 jumlah hipertensi meningkat menjadi 6405 orang dengan persentase 19,7\% dan pada tahun 2012 jumlah penderita hipertensi meningkat menjadi 8292 orang dengan persentase 29,5\% (Dinas Kesehatan Provinsi Bengkulu \& Dinas Kesehatan Rejang Lebong, 2012). Berdasarkan data dari Puskesmas bahwa Puskesmas Perumnas menjadi urutan pertama penyakit hipertensi yang banyak dialami oleh masyarakat yaitu sebesar 1314, Puskesmas Curup sebesar 1277 orang, dan Puskesmas Simpang Nangka 1,3\% (Profil Kesehatan Rejang Lebong, 2013).

Tujuan penelitian adalah untuk mengetahui perbedaan kepatuhan pasien minum obat hipertensi setelah diberikan pendidikan kesehatan di wilayah kerja Puskesmas Perumnas Kabupaten Rejang Lebong Tahun 2014.

\section{BAHAN DAN CARA KERJA}

Hasil wawancara dengan tujuh orang usia dewasa yang mengalami hipertensi dan pernah berobat ke tenaga medis mengatakan bahwa pernah mendapatkan pendidikan kesehatan pada waktu datang berobat dari tenaga kesehatan dan mahasiswa praktik tentang cara minum obat hipertensi. Usia dewasa mengata- 
kan hanya minum obat antihipertensi bila merasakan sakit kepala berat saja dan berhenti minum obat bila keluhan sudah berkurang. Menurut keluarga usia dewasa jarang melakukan pemeriksaan tekanan darah rutin, jarang melakukan diet rendah garam dan rendah lemak, kebiasaan makan ikan asin, tauco dan sambal terasi serta kebiasaan minum kopi dan merokok terutama pada laki-laki. Usia dewasa mengatakan keluarga terkadang mengingatkan untuk minum obat dan menganjurkan untuk melakukan pemeriksaan tekanan darah ke tenaga medis. Alasan usia dewasa tidak minum obat secara teratur karena lupa, bosan dan malas untuk minum obat setiap harinya.

Hasil wawancara dengan tujuh orang usia dewasa yang mengalami hipertensi dan pernah berobat ke tenaga medis mengatakan bahwa pernah mendapatkan pendidikan kesehatan pada waktu datang berobat dari tenaga kesehatan dan mahasiswa praktik tentang cara minum obat hipertensi. Usia dewasa mengatakan hanya minum obat antihipertensi bila merasakan sakit kepala berat saja dan berhenti minum obat bila keluhan sudah berkurang. Menurut keluarga usia dewasa jarang melakukan pemeriksaan tekanan darah rutin, jarang melakukan diet rendah garam dan rendah lemak, kebiasaan makan ikan asin, tauco dan sambal terasi serta kebiasaan minum kopi dan merokok terutama pada laki-laki. Usia dewasa mengatakan keluarga terkadang mengingatkan untuk minum obat dan menganjurkan untuk melakukan pemeriksaan tekanan darah ke tenaga medis. Alasan usia dewasa tidak minum obat secara teratur karena lupa, bosan dan malas untuk minum obat setiap harinya.

Desain penelitian ini menggunakan pendekatan quasi eksperimen, dengan sampel 36 usia dewasa dengan hipertensi, menggunakan kuesioner sebagai instrumen penelitian, prosedur pengambilan data dengan tehnik purposif sampling, pengolahan data menggunakan sistem SPSS.

\section{HASIL}

Pada penelitian ini karakteristik yang diteliti berupa jenis kelamin, lama menderita hipertensi, tingkat hipertensi, jarak rumah
keYankes, dukungan keluarga, pekerjaan, pola makanan dan aktivitas fisik.

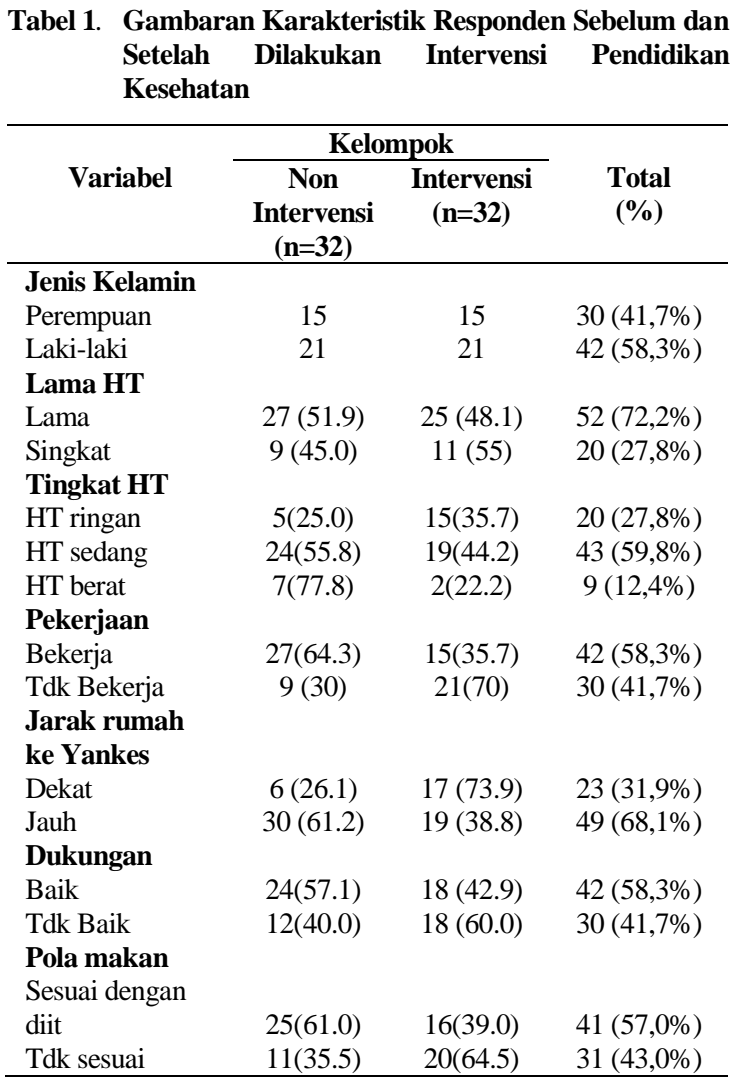

Hasil penelitian menunjukkan bahwa lebih dari setengah responden berjenis kelamin laki-laki, yaitu sebanyak 42 orang $(58,3 \%)$. Mayoritas responden dengan pendidikan rendah yaitu 52 orang $(72,2 \%)$. Tingkat hipertensi responden yaitu tingkat sedang 43 orang $(59,8 \%)$. Sebagian besar responden bekerja yaitu 42 orang $(58,3 \%)$. Jarak rumah ke pelayanan kesehatan sebagian besar jauh yaitu 49 orang $(68,1 \%)$. Dukungan keluarga terhadap program pengobatan sebagian besar baik yaitu 42 orang $(58,3 \%)$. Lebih dari sebagian 41 orang $(57,0 \%)$ dengan pola makan baik.

Tabel 2. Gambaran Kesetaraan Skala Kepatuhan Minum Obat Antihipertensi Sebelum Dilakukan Intervensi Pendidikan Kesehatan

\begin{tabular}{lccc}
\hline $\begin{array}{l}\text { Kepatuhan pasien } \\
\text { minum obat } \\
\text { antihipertensi }\end{array}$ & \multicolumn{2}{c}{ Kelompok } & $\begin{array}{c}\boldsymbol{P} \\
\text { value }\end{array}$ \\
\cline { 1 - 2 } $\begin{array}{l}\text { Tidak patuh } \\
\text { Patuh }\end{array}$ & $\begin{array}{c}30(52.6) \\
\text { Intervensi }\end{array}$ & $\begin{array}{c}27(47.4) \\
\text { valu }\end{array}$ & 0.563 \\
\hline
\end{tabular}

Tabel 2 menunjukkan hasil uji homogenitas kepatuhan minum obat antihipertensi 
sebelum dilakukan intervensi dengan menggunakan uji $\mathrm{T}$ independen didapat nilai $\mathrm{p}>0,05$, berarti variabel pada kelompok kontrol dan intervensi homogen atau setara.

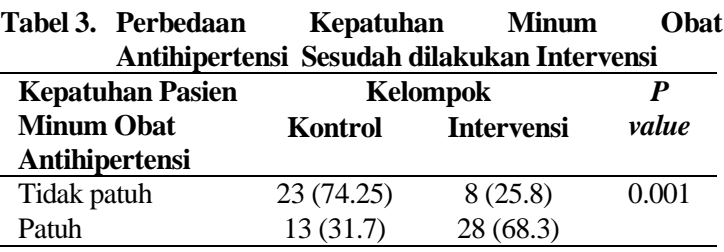

Tabel 3 menunjukkan hasil uji homogenitas kepatuhan minum obat antihipertensi sesudah dilakukan intervensi dengan menggunakan uji $\mathrm{T}$ independen didapat nilai $\mathrm{p}$ value $<0,05$, berarti variabel pada kelompok kontrol dan intervensi tidak homogen atau setara.

\begin{tabular}{lcccc}
\multicolumn{2}{l}{ Tabel 4. Uji Konfonding } & & & \\
\hline \multicolumn{1}{l}{ Karakteristik } & B & SE & $\begin{array}{c}\text { B } \\
(\mathbf{e x p})\end{array}$ & $\boldsymbol{p}$ \\
\hline Jenis Kelamin & 1.698 & 0.914 & 0.255 & 0.247 \\
Pekerjaan & -1.365 & 0.937 & 0.873 & 0.010 \\
Lama Hipertensi & 0,751 & 0,655 & 2,120 & 0,251 \\
$\begin{array}{l}\text { Jarak Rumah } \\
\text { keYankes }\end{array}$ & 0.353 & 0.965 & 1.424 & 0.023 \\
$\begin{array}{l}\text { Dukungan } \\
\text { Keluarga }\end{array}$ & -0.171 & 0.898 & 0.843 & 0.930 \\
Pola Makan & & & & \\
Tekanan darah & -0.374 & 0.858 & 0.688 & 0.270 \\
\hline
\end{tabular}

Berdasarkan tabel 4 uji konfounding diatas, pada tahap pertama terdapat 4 variabel yang memiliki nilaip $\mathrm{p}>0,05$ yaitu jenis kelamin $(\mathrm{p}=0,247)$, lama hipertensi $(\mathrm{p}=0,251)$, dukungan keluarga $(\mathrm{p}=0,930)$ dan pola makan $(\mathrm{p}=0,270)$. Tahap kedua variabel jenis kelamin $(p=0,248)$, lama hipertensi $(p=0,251)$ dan pola makan $(\mathrm{p}=0,271)$.Selanjutnya pada tahap terakhir masih terdapat variabel yang memiliki nilai $\mathrm{p}>0,05$ yaitu jenis kelamin $(\mathrm{p}=0,161)$ dan lama hipertensi $(\mathrm{p}=0,290)$ dengan besar perbedaan OR < 10\%. Pada pemodelan akhir uji konfounding ada 3 variabel yang memiliki nilai $\mathrm{p}<0,05$ yaitu kerja $(\mathrm{p}=0,006)$, jarak rumah $(\mathrm{p}=0,014)$ dan Tekanan darah $(\mathrm{p}=0,017)$.

Tabel 5 menunjukkan bahwa kepatuhan penderita dalam minum obat antihipertensi sebelum dilakukan intervensi pendidikan kesehatan dan intervensi pendidikan kesehatan pada kelompok dapat menjelaskan variasi kepatuhan minum obat antihipertensi sebesar $39,1 \%$.

Tabel 5. Hasil Pemodelan Terakhir Karakteristik yang Paling Berkontribusi terhadap Kepatuhan Minum Obat Antihipertensi

\begin{tabular}{lccccc}
\hline Karakteristik & OR & SE & $\begin{array}{c}\text { B } \\
\text { exp }\end{array}$ & p & $\mathbf{9 5 \%}$ \\
\hline Constanta & - & 2.609 & 0.000 & 0.000 & 0.391 \\
$\begin{array}{l}\text { Kepatuhan } \\
\text { awal }\end{array}$ & 0.052 & & & & \\
\hline
\end{tabular}

Persamaan regresi yang diperoleh adalah :

Kepatuhan minum obat anti hipertensi $=-9.052$

- 1.843 intervensi + 0.384 kepatuhan sebe-

lumnya

Dari pemodelan dapat disimpulkan bahwa : Penderita yang memiliki kepatuhan minum obat anti hipertensi sebesar 1,8 kali. Kelompok yang diberikan pendidikan kesehatan lebih tinggi kepatuhan minum obat anti hipertensi sebesar 0.38 kali setelah dikontrol variable kepatuhan sebelumnya.

\section{PEMBAHASAN}

Hasil menunjukkan bahwa dukungan keluarga berkontribusi untuk tingkat kepatuhan usia dewasa dalam program pengobatan dengan nilai $p$ value 0,849 . Penelitian Hashmi (2009) didapatkan bahwa dukungan keluarga sangat berperan penting untuk keberhasilan dari suatu program pengobatan penyakit kronis. Dukungan keluarga yang baik akan dapat membantu pengobatan penyakit kronis karena keluarga dapat memantau penderita dalam hal pengobatan dan memberikan dukungan yang positif untuk tetap melakukan pola hidup sehat dan minum obat secara rutin.

Kepatuhan pengobatan dalam penelitian ini meningkat setelah diberikan intervensi berupa pendidikan kesehatan, ini sesuai dengan penelitian Sharaf (2010) yang menyatakan bahwa pendidikan kesehatan akan meningkatkan kepatuhan pengobatan yang sedang dijalani oleh pasien pada penyakit kronis. Kepatuhan dalam pengobatan pada dasarnya dipengaruhi oleh banyak faktor dan salah satunya yaitu dengan pemberian pendidikan kesehatan karena pada dasarnya sifat manusia 
akan melakukan tindakan yang dapat menunjang kesehatannya.

Pendidikan kesehatan dipengaruhi oleh ketrampilan untuk dapat merubah perilaku dalam kepatuhan pogram pengobatan (Rickles, 2010). Pendidikan kesehatan yang diberikan menggunakan media audiovisual sangat berpengaruh terhadap perubahan pengetahuan dan sikap (Kapti, 2010). Informasi yang diberikan dengan jelas dan penuh perhatian oleh tenaga kesehatan baik dari bagian farmasi tentang cara pemakaian obat maupun perawat dalam memberian pendidikan kesehatan sangat berpengaruh untuk pasien terutama dalam hal pengobatan khususnya pada pasien dengan penyakit kronis.

Pendidikan kesehatan dapat diberikan melalui telepon (Iversen, 2014). Selain itu buku kontrol untuk penderita hipertensi memiliki potensi sebagai media promosi kesehatan untuk penderita hipertensi primer di puskesmas (Liman, 2014). Pendidikan kesehatan dapat diberikan secara tidak langsung melalui buku kontrol, selain berguna bagi peserta juga bagi tenaga kesehatan dalam memantau pengobatan pasien.

\section{DAFTAR RUJUKAN}

Al-Dabbagh,S,A. and and Aswad,S,M. 2009. Compliance of Hypertensive Patients to Management in Duhok Governorate using MoriskyGreen test. Oxford.

Al-Qasem.A.,Smith.F and Clifford.S. 2011.Adherence to medication among chronic patients in Middle Eastern countries:review of studies. EMHJ.Vol.17 No.4.

Banegas,J,R.,Castillon,P,G.,Artalejo,F,R.,Graciani,A.,Gar cia,E,L., \& Ruilope,L,M. (2006). Association Between Awareness, Treatment, and Control of Hypertension, and Quilty of Life Among Older Adults in Spain. AJH 2006; 19;686-693.

Dinas Kesehatan Provinsi Rejang Lebong.2012

Effendy.N. 2010. Dasar-dasar Keperawatan Kesehatan Masyarakat edisi 2. EGC.

Gupta, R., \& Guptha,S. (2010). Strategies for Initial Management of Hypertension. Indian $\mathrm{J}$ Med Res.2010 November; 132(5): 531-542.

Hashmi.K.S.,Afridi.M.B.,Abbas.K.,Sajwani.R.A.,Salehee n.D.,...Ahmad.U. 2007. Factor Associated with Adherence to Anti-Hypertensive Treatment in Pakistan.www.polosone.org.

\section{KESIMPULAN}

Hasil penelitian menunjukkan bahwa jenis kelamin responden terbanyak laki-laki, waktu lama menderita hipertensi, dengan tingkat hipertensi sedang, dan jarak rumah ke pelayanan kesehatan dekat. Untuk dukungan keluarga terbanyak adalah baik, status pekerjaan bekerja dengan pola makan makanan yang sesuai dengan diit, serta melakukan aktivitas tidak sesuai dengan standar kesehatan. Ada perbedaan rerata kepatuhan minum obat antihipertensi antara kelompok intervensi dengan kelompok kontrol setelah dilakukan pendidikan kesehatan.

Bagi tenaga kesehatan khususnya perawat kesehatan komunitas untuk dapat meningkatkan kegiatan pendidikan kesehatan pada masyarakat khususnya pada usia dewasa dengan hipertensi dengan menggunakan metoda yang pervariasi agar dapat menarik minat masyarakat untuk ikut serta dan mengaplikasinya dalam kehidupan sehari-hari mereka.

Hashmi.S.K.,et.al. 2007. Factors Associated with Adherence to Anti-Hypertensive Treatmen in Pakistan.

Kapti. (2010). Efektifitas Audiovisual sebagai Media Penyuluhan Kesehatan Terhadap terhadap Peningkatan Pengetahuan dan Sikap Ibu dalam Tatalaksana Balita dengan Diare di dua rumah Sakit Kota Malang. Fakultas Ilmu Keperawatan Universitas Indonesia.

Kemenkes RI. 2010. Profil Pengendalian Penyakit dan Penyehatan Lingkungan Tahun 2010. Directorat Jenderal Pengendalian Penyakit dan Penyehatan Lingkungan.

Kumboyo. (2011). Perbedaan Efek Penyuluhan Kesehatan Menggunakan Media Cetak Dengan Media Audio Visual Terhadap Peningkatan Pengetahuan Pasien Tuberkulosis. Program Studi Ilmu Keperawatan FK Universitas Brawijaya. Jurnal Ilmiah Kesehatan Keperawatan, Volume 7, No. 1, Februari 2011.

Nainggolan,Delima Fitri Partilia., Yuni Armiyati., \& Mamat Supriyono. 2012. Hubungan dukungan Keluarga dengan Kepatuhan Diit Rendah Garam dan Keteraturan Kontrol Tekanan Darah pada Penderita Hipertensi di Poliklinik RSUD Tugurejo 
Semarang. Diunduh dari www.academia.edu/7385190 pada tanggal 12 Desember 2014

Meylina, Elin (2005). Analisisi Faktor Risiko Hipertensi, Diabetes Melitus, Penyakit Jantung dan Pembuluh Darah Di Indonesia.

Ramli.A.,Ahmad.N.S.,Paraidathathu.T. 2012. Medication adherence among Hypertensive patients of primary health clinics in Malaysia. Journal Patient Preverence and Adherence 2012:6 613-622.

Rickles, Brown, McGivney, Snyder, White. Adherence: a review of education, research, practice, and policy in the United States. Pharmacy Practice (Internet) 2010 Jan-Mar;8(1):1-
Septiyani.R.D. (2010). Pengaruh Tipe Kepribadian dengan Derajat Pada Pasien Hipertensi Wanita 3050 di Puskesmas Gilingan Surakarta.

Sharaf, Fawzy. 2010. Impact of health education on compliance among patients of chronic diseases in Al Qassim, Saudi Arabia. www.ijhs.org.sa/Qassim University, International Journal of Health Sciences, Vol.4,No.2

Stanhope.M., \& Lancaster.J. 2005. Community Health Nursing Promoting Health of Aggregates, Families and Individuals. Mosby.

WHO. (2011). Health education: theoretical concepts, effective strategies and core competencies. http://applications.emro.who.int 